\title{
EFFECT OF COMPOSITION OF THE MEDIUM ON UTILIZATION OF ALLYL ALCOHOL BY TRICHODERMA VIRIDE
}

\author{
R.B. JACKSON \\ C.S.I.R.O., Division of Soils, Glen Osmond, South Australia. 5064
}

(Received May 15, 1971)

\begin{abstract}
The nutritional requirements for rapid utilization of allyl alcohol in shaken flask cultures were investigated for a strain of Trichoderma viride isolated from soil. Single variable and factorial experiments were used to determine the effects of various nitrogen sources and concentrations of phosphate, allyl alcohol, glucose, and yeast extract on utilization of allyl alcohol.

Ammonia was a better nitrogen source than nitrate. Urea, also, was suitable provided the culture was kept below about $\mathrm{pH}$ 6.5.

Phosphate as high as $0.1 \mathrm{M}$ did not inhibit and the improved $\mathrm{pH}$ control favoured allyl alcohol utilization. Glucose or yeast extract stimulated allyl alcohol utilization, the maximum effect being achieved at $1 \mathrm{~g}$ of glucose/liter.
\end{abstract}

Allyl alcohol has been used as a soil fumigant and herbicide for about 20 years. JENSEN (1) found that allyl alcohol was decomposed rapidly by the soil microflora and concluded that Pseudomonas fluorescens and Trichoderma viride were the organisms largely responsible for its decomposition. Some aspects of the metabolism of allyl alcohol by Pseudomonas fuorescens and Nocardia corallina were described by JENSEN (2) but studies with Trichoderma viride have not been reported.

This paper describes the isolation from soil of a strain of Trichoderma viride able to utilize allyl alcohol and the effects of medium composition on allyl alcohol uptake by the fungus. Conditions were defined for the production of young, active mycelium suitable for metabolic studies. The media constituents were investigated either with single variables or with two variables in factorial design.

\section{MATERIALS AND METHODS}

Allyl alcohol. Laboratory reagent grade allyl alcohol was dried over anhydrous $\mathrm{K}_{2} \mathrm{CO}_{3}$ and then fractionally distilled through a $36 \mathrm{~cm}$ Vigreux column. The fraction used contained less than $0.1 \% n$-propanol by gas chromatographic analysis but no other impurities were detected.

Media. The media used for isolation and purification of the organism 
Table 1. Media for isolation of $T$. viride and preparation of inocula.

\begin{tabular}{l|c|c|c|c}
\hline & A & B & C & D \\
\hline $\mathrm{NH}_{4} \mathrm{Cl}(\mathrm{g})$ & - & - & 1.34 & 1.34 \\
$\mathrm{NH}_{4} \mathrm{NO}_{3}(\mathrm{~g})$ & 0.80 & - & - & - \\
$\mathrm{NaNO}_{3}(\mathrm{~g})$ & - & 2.1 & - & - \\
$\mathrm{KH}_{2} \mathrm{PO}_{4}(\mathrm{~g})$ & 1.36 & 1.36 & 1.36 & 13.6 \\
$\mathrm{KCl}(\mathrm{g})$ & 0.37 & 0.37 & - & - \\
$\mathrm{MgSO}_{4} \cdot 7 \mathrm{H}_{2} \mathrm{O}(\mathrm{g})$ & 0.49 & 0.49 & 0.49 & 0.49 \\
Trace elements $^{a}$ & + & + & + & + \\
Distilled water (ml) & 1000 & 1000 & 1000 & 1000 \\
$\mathrm{pH}^{b}$ & 4.5 & 5.5 & 5.5 & 5.5 \\
Difco yeast extract (g) & - & 0.2 & 0.2 & - \\
Glucose (g) & - & - & - & 0.5 \\
Allyl alcohol (ml) & 5 & 5 & 5 & 5 \\
\hline
\end{tabular}

a Trace elements were added to all media in two solutions: (i) $0.2 \mathrm{ml} / \mathrm{liter}$ $\mathrm{Na}_{2} \mathrm{MoO}_{4}(50 \mathrm{~mm})$ and (ii) $1.0 \mathrm{ml} /$ liter of a solution containing $\mathrm{FeCl}_{3}(50 \mathrm{mM}), \mathrm{CaCl}_{2}$ (100 mM), $\mathrm{MnCl}_{2}(20 \mathrm{mM}), \mathrm{ZnCl}_{2}(10 \mathrm{~mm}), \mathrm{CuCl}_{2}(2 \mathrm{mM})$, and $\mathrm{CoCl}_{2}(2 \mathrm{~mm})$, adjusted to $\mathrm{pH} 2$ with $\mathrm{HCl}$.

$b$ When required, $\mathrm{pH}$ was adjusted with $\mathrm{NaOH}$ before autoclaving.

and for preparation of inocula are defined in Table 1 . Other media will be described in the legends to figures and tables. Allyl alcohol was added aseptically to the autoclaved media. Glucose and Difco yeast extract were autoclaved separately as $10 \%$ and $1 \%$ solutions, respectively, urea solution $(1 \mathrm{M})$ was sterilized by filtration, and $\mathrm{CaCO}_{3}$ was autoclaved separately; these four components were aseptically added, when required, to the sterilized mineral media.

Microorganism. An enrichment culture was established by adding $50 \mu \mathrm{l}$ of allyl alcohol to $100 \mathrm{~g}$ moist garden soil and incubating at $25^{\circ}$. After 3 weeks an additional $50 \mu 1$ of allyl alcohol was added and incubation continued for 1 week when $0.5 \mathrm{~g}$ of this enriched soil was added to $100 \mathrm{ml}$ medium A (Table 1). The suspension was incubated at $25^{\circ}$ on a rotary shaker for 4 days when an aliquot was transferred to fresh medium. After three further serial transfers using medium A to which Difco yeast extract $(100 \mathrm{mg} / \mathrm{liter})$ had been added, the suspension of mycelium was blended at about 9,000 rpm in a Sorvall Omni-mixer (Ivan Sorvall, Inc., Norwalk, Connecticut, U.S.A.), serially diluted and streaked on plates of the same medium solidified with agar $(20 \mathrm{~g} /$ liter). Small pieces of young mycelium were cut out and purified by further plating. The fungus obtained was identified as Trichoderma viride (3). Stock cultures were maintained on agar slants of medium A to which yeast extract $(0.2 \mathrm{~g} /$ liter $)$ had been added. Freshly inoculated slants were incubated at $25^{\circ}$ until extensive sporing had occurred and then stored at $0-2^{\circ}$. 
Inoculum. Two or three flasks, each containing $100 \mathrm{ml}$ medium, were inoculated with conidia from an agar slant and incubated at $25^{\circ}$ on a rotary shaker. After 3 days the mycelial suspension was centrifuged, the supernatant decanted, and the mycelium washed with 0.5 volume of the appropriate basal medium. The washed mycelium was blended with a suitable volume of basal medium in an Omni-mixer at about $9,000 \mathrm{rpm}$ for $15 \mathrm{sec}$ and $10 \mathrm{ml}$ suspension used to inoculate $100 \mathrm{ml}$ medium in a $500-\mathrm{ml}$ conical flask.

Estimation of allyl alcohol. Allyl alcohol was estimated by gas-liquid chromatography using a modification of the head-space technique of BASSETTE et al. (4). Both ethanol and propanol were suitable internal standards provided they were not metabolic products. Qualitative analyses of culture fluids from several experiments indicated that neither ethanol nor propanol accumulated, but as a further check, both internal standards were generally used so that their occurrence in culture fluids would have been revealed by deviations from the ethanol/propanol peak-height ratio of the standard mixtures, unless the ratio produced had been similar to that added.

Samples of culture fluid $(2.0 \mathrm{ml})$ were added to $25-\mathrm{ml}$ conical flasks and known amounts of ethanol and propanol were added. Anhydrous $\mathrm{Na}_{2} \mathrm{SO}_{4}$ $(2 \mathrm{~g})$ was added and the flask closed with a rubber vaccine cap. The flask was kept at $25^{\circ}$ and swirled gently from time to time. After at least $20 \mathrm{~min}$, 250- $\mu 1$ samples of the vapour phase were withdrawn with a syringe and injected into a gas chromatograph (Model 609 flame ionization; HewlettPackard F and M Scientific Division, U.S.A.). The stainless steel column $(180 \mathrm{~cm} \times 4 \mathrm{~mm})$ was packed with Carbowax $20 \mathrm{M}(5 \%, \mathrm{w} / \mathrm{w})$ adsorbed on a fluoroethylene polymer (Haloport F; Hewlett-Packard). Nitrogen gas was passed through the column at a flow rate of $50 \mathrm{ml} / \mathrm{min}$. The operating temperatures were : column, $75^{\circ}$; injection port, $110^{\circ}$, and detector, $110^{\circ}$. Allyl alcohol peak heights, relative to the internal standards, were proportional to concentration over the range tested $(0-10 \mathrm{ml} /$ liter $)$.

Dry weight of mycelium. Mycelium was collected on tared sintered filters, washed with water, and dried at $85^{\circ}$ for $24 \mathrm{hr}$.

\section{RESULTS}

\section{Effect of blending time of inoculum}

The inocula used for these studies were prepared by fragmentation of mycelium in a high-speed propeller type blender (5). Such treatment, if prolonged, is detrimental to some fungi $(6,7)$. The effect of blending-time on subsequent consumption of allyl alcohol by Trichoderma viride is shown in Table 2. Blending for at least $10 \mathrm{sec}$ was required for adequate fragmentation while treatment for as long as $30 \mathrm{sec}$ was not detrimental.

\section{Effect of nitrogen sources}

The fungus was grown in shake flasks on four different nitrogen sources, 


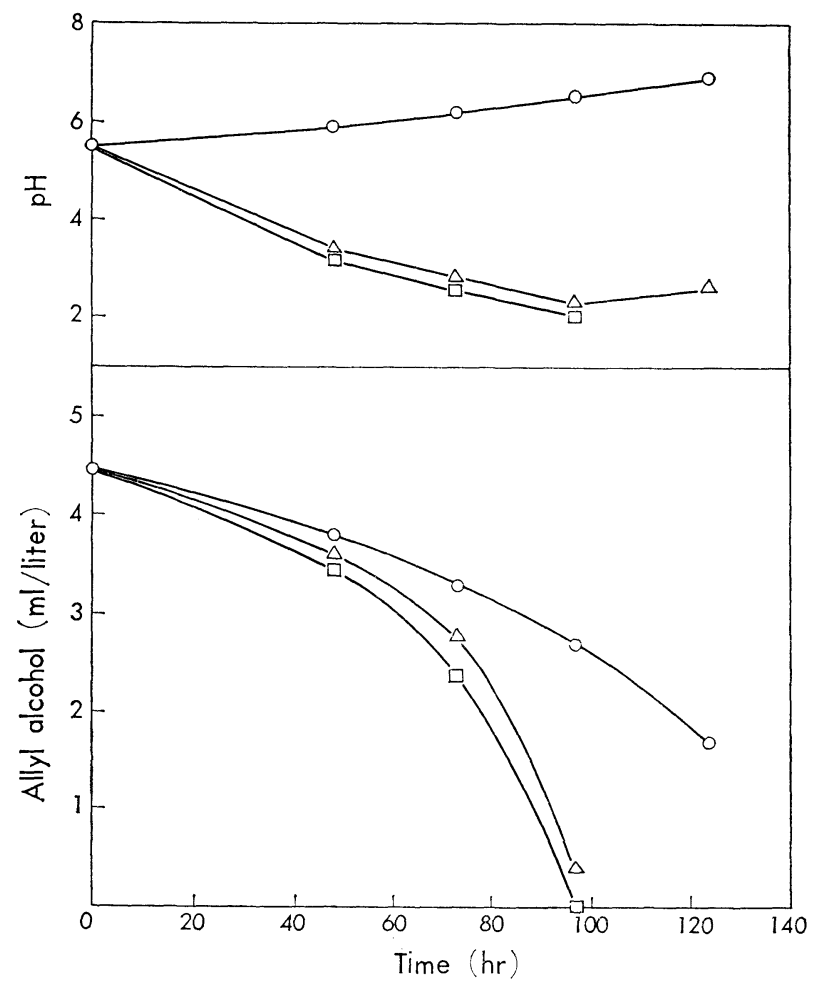

Fig. 1. Effect of nitrogen source on allyl alcohol uptake and $\mathrm{pH}$.

Basal medium: $1.36 \mathrm{~g} \mathrm{KH}_{2} \mathrm{PO}_{4}, 0.49 \mathrm{~g} \mathrm{MgSO}_{4} \cdot 7 \mathrm{H}_{2} \mathrm{O}$, trace elements (Table 1), $0.2 \mathrm{~g}$ Difco yeast extract, and $1,000 \mathrm{ml}$ water, $\mathrm{pH}$ 5.5. Inoculum : Grown in medium $\mathrm{B}$ (Table 1), washed, and blended in basal medium.

○, $25 \mathrm{~mm} \mathrm{NaNO}_{3} ; \triangle, 12.5 \mathrm{mM} \mathrm{NH}_{4} \mathrm{NO}_{3} ; \square, 25 \mathrm{~mm} \mathrm{NH} \mathrm{NH}_{4} \mathrm{Cl}$ or $12.5 \mathrm{~mm}\left(\mathrm{NH}_{4}\right)_{2} \mathrm{SO}_{4}$.

Table 2. Effect of blending time of inoculum on allyl alcohol uptake.

\begin{tabular}{|c|c|c|c|c|}
\hline \multirow{3}{*}{$\begin{array}{c}\text { Period of incubation } \\
\text { (days) }\end{array}$} & \multicolumn{4}{|c|}{ Allyl alcohol consumed (ml/liter) } \\
\hline & \multicolumn{4}{|c|}{ Blending period (sec) } \\
\hline & 5 & 10 & 20 & 30 \\
\hline 1 & 0.1 & 0.2 & 0.2 & 0.2 \\
\hline 2 & 0.2 & 0.8 & 0.8 & 0.8 \\
\hline 3 & 0.5 & 1.4 & 1.5 & 1.5 \\
\hline 4 & 0.7 & 2.1 & 2.4 & 2.5 \\
\hline 5 & 1.0 & 4.1 & 4.4 & 4.5 \\
\hline
\end{tabular}

Medium B (Table 1) 


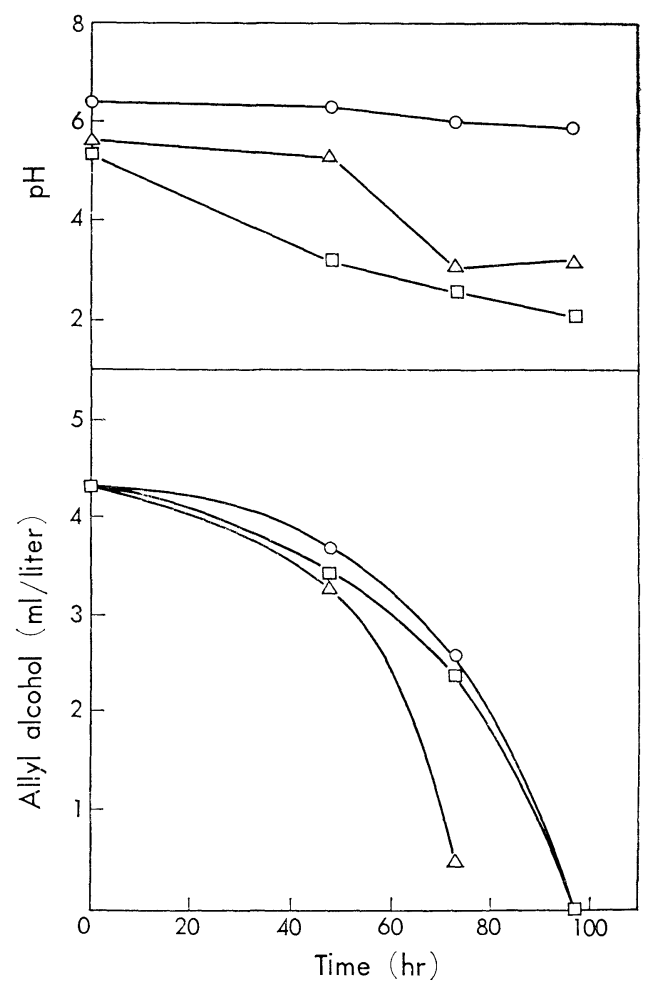

Fig. 2. Effect of buffer capacity on allyl alcohol uptake and $\mathrm{pH}$.

Basal medium: $1.34 \mathrm{~g} \mathrm{NH}{ }_{4} \mathrm{Cl}, 1.36 \mathrm{~g} \mathrm{KH}_{2} \mathrm{PO}_{4}, 0.49 \mathrm{~g} \mathrm{MgSO}_{4} \cdot 7 \mathrm{H}_{2} \mathrm{O}$, trace elements (Table 1), $0.2 \mathrm{~g}$ Difco yeast extract, and $1,000 \mathrm{ml}$ water, $\mathrm{pH}$ 5.5. Inoculum: Grown in medium B (Table 1), washed, and blended in basal medium.

$\square, 10 \mathrm{mM} \mathrm{KH}_{2} \mathrm{PO}_{4} ; \triangle, 100 \mathrm{mM} \mathrm{KH}_{2} \mathrm{PO}_{4} ; \bigcirc, 50 \mathrm{~m}$ mole $\mathrm{CaCO}_{3}$ per liter.

each at a concentration of $25 \mathrm{mg}$-atoms N/liter. Figure 1 shows that $\mathrm{NH}_{4} \mathrm{Cl}$ and $\left(\mathrm{NH}_{4}\right)_{2} \mathrm{SO}_{4}$ gave identical results and were slightly superior to $\mathrm{NH}_{4} \mathrm{NO}_{3}$. The three ammonium salts gave greater uptake of allyl alcohol than $\mathrm{NaNO}_{3}$. The $\mathrm{pH}$ of the cultures containing ammonium salts fell markedly but with $\mathrm{NaNO}_{3}$ the $\mathrm{pH}$ rose.

\section{Effect of increased buffer capacity}

The low $\mathrm{pH}$ produced when ammonium salts were used might have inhibited growth of the fungus $(8)$. The buffer capacity of the medium was therefore increased, either by increasing the phosphate concentration or by adding $\mathrm{CaCO}_{3}(0.05$ mole/liter). Figure 2 shows that $0.1 \mathrm{M}$ phosphate retarded the fall in $\mathrm{pH}$ and gave a more rapid uptake of allyl alcohol. Calcium 
Table 3. Effect of nitrogen source and phosphate concentration on allyl alcohol uptake and $\mathrm{pH}$.

\begin{tabular}{|c|c|c|c|c|}
\hline \multirow{2}{*}{$\mathrm{N}$ source } & \multirow{2}{*}{$\begin{array}{l}\text { Phosphate } \\
\text { (mM) }\end{array}$} & \multicolumn{3}{|c|}{$\begin{array}{l}\text { Allyl alcohol used }(\mathrm{ml} / \text { liter }) \\
\text { and } \mathrm{pH} \text { values }\end{array}$} \\
\hline & & $24 \mathrm{hr}$ & $48 \mathrm{hr}$ & $72 \mathrm{hr}$ \\
\hline $\begin{array}{l}\mathrm{NH}_{4} \mathrm{Cl} \\
\quad(25 \mathrm{mM})\end{array}$ & $\begin{array}{r}25 \\
100\end{array}$ & $\begin{array}{c}1.2 \\
(3.2)^{b} \\
1.0 \\
(4.3)\end{array}$ & $\begin{array}{c}2.3 \\
(2.7) \\
3.5 \\
(3.2)\end{array}$ & $\begin{array}{c}6.1 \\
(2.2) \\
5.8 \\
(3.0)\end{array}$ \\
\hline $\begin{array}{c}\left(\mathrm{NH}_{4}\right) \mathrm{H}_{2} \mathrm{PO}_{4} \\
(25 \mathrm{mM})\end{array}$ & $\begin{array}{r}25 \\
100\end{array}$ & $\begin{array}{c}1.4 \\
(3.3) \\
1.0 \\
(4.6)\end{array}$ & $\begin{array}{c}2.6 \\
(2.8) \\
3.8 \\
(3.3)\end{array}$ & $\begin{array}{c}6.0 \\
(2.4) \\
5.2 \\
(3.2)\end{array}$ \\
\hline $\begin{array}{l}\text { Urea } \\
\qquad(12.5 \mathrm{~mm})\end{array}$ & $\begin{array}{r}25 \\
100\end{array}$ & $\begin{array}{c}0.9 \\
(6.0) \\
1.5 \\
(5.7)\end{array}$ & $\begin{array}{c}2.5 \\
(6.2) \\
3.6 \\
(5.4)\end{array}$ & $\begin{array}{c}6.0 \\
(3.8) \\
6.1 \\
(4.1)\end{array}$ \\
\hline
\end{tabular}

Basal medium: $0.49 \mathrm{~g} \mathrm{MgSO}_{4} \cdot 7 \mathrm{H}_{2} \mathrm{O}$, trace elements (Table 1), $0.5 \mathrm{~g}$ glucose and $1000 \mathrm{ml}$ water, $\mathrm{pH} 5.5$.

Inoculum: Grown in medium D (Table 1), washed, and blended in basal medium.

a Initial concentration of allyl alcohol, $7.3 \mathrm{ml} /$ liter.

$b \mathrm{pH}$ values in parentheses; initial $\mathrm{pH}$ values $5.5-5.7$.

carbonate prevented the $\mathrm{pH}$ falling but did not increase allyl alcohol uptake and, as it caused extensive clumping of mycelium, its use was not investigated further.

\section{Effect of phosphate concentration with various sources of nitrogen}

Optimum concentrations of phosphate reported for fungi are usually in the range 1 to $3 \mathrm{mM}(9)$ and concentrations as high as $100 \mathrm{~mm}$ inhibit some fungi (10). Ammonium phosphate and urea have been used as nitrogen sources to prevent a large drop in $\mathrm{pH}$ caused by preferential utilization of the cation (8). The results of a comparison of $\mathrm{NH}_{4} \mathrm{Cl}$, ammonium phosphate, and urea at 25 and $100 \mathrm{~mm}$ phosphate are shown in Table 3 . At both phosphate levels ammonium phosphate and chloride gave similar results for both $\mathrm{pH}$ and allyl alcohol uptake. With urea the $\mathrm{pH}$ did not fall so low as with the ammonium salts. After $48 \mathrm{hr}$ of incubation, the $100 \mathrm{mM}$ phosphate level gave greater allyl alcohol utilization than $25 \mathrm{~mm}$ phosphate regardless of the nitrogen source but this difference had disappeared after $72-\mathrm{hr}$ incubation. With urea the $\mathrm{pH}$ rose in the early stages and subsequently fell, the changes being more marked at the lower phosphate level. 
Table 4. Comparison of $\mathrm{NH}_{4} \mathrm{Cl}$ and urea as nitrogen sources at three phosphate concentrations.

\begin{tabular}{c|c|c|c|c}
\hline \multirow{2}{*}{$\mathrm{N}$ source } & $\begin{array}{c}\text { Phosphate } \\
(\mathrm{mm})\end{array}$ & Final $\mathrm{pH}^{a}$ & $\begin{array}{c}\text { Allyl alcohol } \\
\text { used } \\
\text { (ml/liter) }\end{array}$ & $\begin{array}{c}\text { Dry weight } \\
\text { (g/liter) }\end{array}$ \\
\hline \multirow{3}{*}{$\mathrm{NH}_{4} \mathrm{Cl}(25 \mathrm{~mm})$} & 10 & 2.6 & 1.6 & 1.3 \\
& 25 & 2.8 & 1.9 & 1.6 \\
& 100 & 5.2 & 2.1 & 1.6 \\
\hline \multirow{3}{*}{ Urea (12.5 mM) } & 10 & 7.7 & 0.8 & 0.8 \\
& 25 & 7.1 & 1.5 & 1.3 \\
& 100 & 6.4 & 2.2 & 1.7 \\
\hline
\end{tabular}

Basal medium and inoculum as described for Table 3 .

Cultures incubated on rotary shaker for $48 \mathrm{hr}$ at temperature of $25^{\circ}$.

a Initial $\mathrm{pH} 6.0$.

$b$ Initial concentration of allyl alcohol, $6.1 \mathrm{ml} /$ liter.

The study of the interaction of phosphate concentration and nitrogen source was extended by comparing $\mathrm{NH}_{4} \mathrm{Cl}$ and urea at three phosphate levels (Table 4). $\mathrm{NH}_{4} \mathrm{Cl}$ and urea gave similar results at $100 \mathrm{mM}$ phosphate, but at the lower phosphate concentrations, particularly $10 \mathrm{mM}, \mathrm{NH}_{4} \mathrm{Cl}$ gave better growth and allyl alcohol utilization.

\section{Effect of yeast extract and glucose}

During the isolation and purification of the fungus it was found that growth and allyl alcohol uptake were stimulated by small amounts of Difco yeast extract. To determine whether stimulation was due to the provision of growth factors or simply to the supply of more acceptable nitrogen or carbon sources, a factorial experiment was carried out with two levels of yeast extract and two levels of glucose. Table 5 shows that, although the amounts of glucose and yeast extract used were not equal, glucose was at least as effective as yeast extract in promoting allyl alcohol uptake; the maximum effect was reached at about $1 \mathrm{~g} /$ liter.

\section{Effect of allyl alcohol concentration}

Since glucose stimulated allyl alcohol uptake, three levels of allyl alcohol were tested factorially with three levels of glucose. The uptakes of allyl alcohol after 42 and $66 \mathrm{hr}$ of incubation are shown in Table 6 . After $42 \mathrm{hr}$ of incubation, increased uptake at $0.5 \mathrm{~g}$ of glucose/liter was apparent only at the highest allyl alcohol concentration ( $7.1 \mathrm{ml} /$ liter). Raising of the glucose concentration from 0.5 to $1.0 \mathrm{~g} /$ liter or higher gave increased uptake at all allyl alcohol levels. At the lowest level allyl alcohol was almost exhausted after $42 \mathrm{hr}$. After $66 \mathrm{hr}$ of incubation, the highest allyl alcohol level still 
Table 5. Effect of glucose and yeast extract concentrations on allyl alcohol uptake.

\begin{tabular}{l|c|c|c}
\hline $\begin{array}{c}\text { Glucose } \\
\text { (g/liter) }\end{array}$ & $\begin{array}{c}\text { Yeast extract } \\
\text { (g/liter) }\end{array}$ & Allyl alcohol used ${ }^{a}$ (ml/liter) \\
\hline \multirow{2}{*}{0} & 0 & $48 \mathrm{hr}$ & $72 \mathrm{hr}$ \\
\hline \multirow{2}{*}{0.5} & 0.2 & 0 & 0.2 \\
& 0.4 & 0.3 & 0.7 \\
& 0 & 0.3 & 1.3 \\
\hline \multirow{2}{*}{1.0} & 0.2 & 1.0 & 3.3 \\
& 0.4 & 1.7 & 4.5 \\
\hline
\end{tabular}

Basal medium: $13.6 \mathrm{~g} \mathrm{KH}_{2} \mathrm{PO}_{4}, 1.34 \mathrm{~g} \mathrm{NH}_{4} \mathrm{Cl}, 0.49 \mathrm{~g} \mathrm{MgSO}_{4} \cdot 7 \mathrm{H}_{2} \mathrm{O}$, trace elements (Table 1), and $1,000 \mathrm{ml}$ water, $\mathrm{pH} 5.5$.

Inoculum: Grown in medium C (Table 1), washed, and blended in basal medium.

a Initial concentration of allyl alcohol, $4.7 \mathrm{ml} /$ liter.

Table 6. Effect of allyl alcohol and glucose concentrations on allyl alcohol uptake.

\begin{tabular}{c|c|c|c}
\hline \multirow{2}{*}{$\begin{array}{c}\text { Allyl alcohol } \\
\text { (ml/liter) }\end{array}$} & $\begin{array}{c}\text { Glucose } \\
\text { (g/liter) }\end{array}$ & $42 \mathrm{hr}$ & $66 \mathrm{hr}$ \\
\hline \multirow{2}{*}{2.7} & 0.5 & 1.4 & 2.7 \\
& 1.0 & 2.5 & 2.7 \\
& 1.5 & 2.5 & 2.7 \\
\hline \multirow{3}{*}{4.6} & 0.5 & 1.3 & 4.1 \\
& 1.0 & 2.7 & 4.5 \\
& 1.5 & 2.8 & 4.3 \\
\hline \multirow{3}{*}{7.1} & 0.5 & 2.4 & 5.3 \\
& 1.0 & 3.0 & 5.4 \\
\hline
\end{tabular}

Basal medium: As described for Table 5.

Inoculum: Grown in medium D (Table 1), washed, and blended in basal medium. 
gave the greatest uptake. The early differences due to glucose concentrations were not maintained over a longer incubation period.

\section{DISCUSSION}

The present work has defined some of the characteristics of a simple medium suitable for rapid utilization of allyl alcohol by Trichoderma viride.

Allyl alcohol utilization was faster with ammonium salts than with nitrate, despite the low $\mathrm{pH}$ which developed with ammonium salts. This rapid and large drop in $\mathrm{pH}$ due to preferential use of the cation of ammonium salts has been demonstrated with many fungi $(8)$. MorTON and MACMILlan ( 6 ) found that Trichoderma viride assimilated ammonia more rapidly than nitrate, and BLUMER (11) obtained better growth with ammonia than with nitrate. Addition of $\mathrm{CaCO}_{3}$ to the medium or the use of urea as the nitrogen source prevented the large drop in $\mathrm{pH}$; $\mathrm{CaCO}_{3}$ had little effect on allyl alcohol uptake but urea gave lower uptake than $\mathrm{NH}_{4} \mathrm{Cl}$ at low phosphate concentrations. With urea, weakly buffered cultures developed a high $\mathrm{pH}$ which was probably caused by accumulation of ammonia. Such cultures utilized substrate slowly.

Increasing the phosphate buffer concentration from 0.01 to $0.1 \mathrm{M}$ resulted in greater utilization of allyl alcohol, particularly during the earlier stages of incubation. This effect was probably due to maintenance of favorable $\mathrm{pH}$ for longer periods.

Allyl alcohol is toxic to some microorganisms at concentrations as low as $150 \mathrm{mg} /$ liter (12). In the present work, concentrations up to $6 \mathrm{~g} /$ liter have been used without any apparent toxicity to the fungus.

In general, the lower monohydric aliphatic alcohols are not well utilized by fungi (13) and the stimulation of allyl alcohol utilization by yeast extract or glucose suggests that these substances are more acceptable carbon sources. Glucose is readily assimilated by Trichoderma viride $(6,14,15)$ but did not appear to repress allyl alcohol uptake. The promotion of utilization of the main carbon source by small amounts of glucose has been observed in several fungi $(13,16)$. It is usually postulated that glucose allows sufficient growth so that an enzyme essential for utilization of the main carbon source can be synthesized (13). The enzyme induction hypothesis, however, is not satisfactory for some cases (17) and further study of utilization of mixed carbon sources is desirable.

On the basis of these results, medium D (Table 1) was selected for production of mycelium for subsequent metabolic studies.

\section{REFERENCES}

1) H.L. JENSEN, Nature, 183, 903 (1959).

2) H.L. Jensen, Acta Agr. Scand., 11, 54 (1961).

3) G.L. BARRon, The Genera of Hyphomycetes from Soil, The Williams and Wilkins Co., Baltimore (1968), p. 306. 
4) R. Bassette, S. Özeris and C.H. Whitnah, Anal. Chem., 34, 1540 (1962).

5) J.W. Foster, Chemical Activities of Fungi, Academic Press Inc., New York (1949), p. 62 .

6) A.G. Morton and A. MacMillan, J. Exptl. Botany, 5, 232 (1954).

7) G.M. Savage and M.J. Vander Brook, J. Bacteriol., 52, 385 (1946).

8) V.W. Cochrane, Physiology of Fungi, John Wiley \& Sons, Inc., New York (1958), Chapter 8.

9) V.W. Cochrane, Physiology of Fungi, John Wiley \& Sons, Inc., New York (1958), Chapter 9.

10) J.M. Crasemann, Am. J. Botany, 41, 302 (1954).

11) S. Blumer, Ber. schweiz, botan. Ges., 54, 605 (1944).

12) J.G. Kharitonova and L.K. YaKobi, Chem. Abstr., 69, 69564 (1968).

13) V.W. Cochrane, Physiology of Fungi, John Wiley \& Sons, Inc., New York (1958), Chapter 3.

14) P.W. Brian, P.J. Curtis and H.G. Hemming, Trans. Brit. Mycol. Soc., 29, 173 (1946).

15) E.W. Simon and G.E. Blackman, Symposia Soc. Exptl. Biol., 3, 253 (1949).

16) D.E. Sistrom and L. MACHLIS, J. Bacteriol., 70, 50 (1955).

17) R.A. Steinberg, J. Agr. Research, 59, 749 (1939). 